\title{
MOTYWY PIĘCIOKSIĘGU W KSIĘDZE OZEASZA
}

W Księdze Ozeasza istnieje zadziwiający splot skrajnych idei i emocji: gniew i odkupienie, sąd i miłość, zdrada i przebaczenie. Są one podjęte na nowo szczególnie w Księdze Powtórzonego Prawa, u Jeremiasza i Deuteroizajasza. ${ }^{1}$ Łączy on ze sobą idee sądu z przekazem nadziei i odnowienie, inaczej niż współczesny mu Amos. Ozeasz jako tło swojej działalności ma rozkwitające gospodarczo Królestwo Północne pod rządami Jeroboama II (786-746 przed Chr.). ${ }^{2}$ W swojej refleksji podejmuje wiele motywów, które możemy odnaleźć w Pięcioksięgu.

Jak wiadomo, dyskusja nad datą powstania Tory jest ciągle żywa i aktualna. ${ }^{3} \mathrm{~W}$ ostatnich dziesięcioleciach nastąpiła rewolucja, która zdezaktualizowała model czterech źródeł zaproponowany przez Welhausena i jego następców. Jahwista, który uchodził za najstarszego z ,czterech braci”, raptem po publikacjach Satersa stał się młodzikiem, a Elohista, niestety, wydaje się, że nie wytrzymał tej egzegetycznej chirurgii i znikł zupełnie. Wielką rolę w tych ustaleniach pełni Księga Ozeasza, która w obiegowej opinii uchodzi za jeden

1 B. C. B i r c h, Hosea, Joel and Amos, Westminster 1997, s. 8; S. P a a s, Creation \& Judgement. Creation Texts in Some Eighth Century Prophets, Brill, Leiden 2003, s. 327-358.

2 Różne teoria związane $\mathrm{z}$ datowaniem redakcji poszczególnych części $\mathrm{Oz}$ można znaleźć w artykule W. S c h ü t t e, Die Entstehung der juda-exilischen Hoseaschrift, Biblica 95 (2014) 2, s. 198-223.

3 J. L e m a ń s k i, Księga Rodzaju. Rozdziały 1-11. Wstęp. Przekład z oryginału. Komentarz, NKB I/1, Święty Paweł, Częstochowa 2013, s. 49-92; F. G i u n t o 1 i, Genesi 1-11. Introduzione, traduzione e commento, Nuovissima Versione della Bibbia dai Testi Antichi 1.1, San Paolo, Cinisello Balsamo 2013, s. 29-48. 
z najstarszych tekstów biblijnych. ${ }^{4}$ Należy jednak zauważyć, że kolejne, nowsze, publikacje zawierają coraz śmielsze tezy próbujące ukazać tę księge jako dzieło powygnaniowe. ${ }^{5}$ Zadaniem tego artykułu nie jest ustalenie chronologii. Chcielibyśmy ukazać kilka motywów tematycznych i leksykalnych, które są wspólne dla Ozeasza i ksiąg Pięcioksięgu, a które, być może, pomogą nam zobaczyć, że wiele tematów Tory było przedmiotem refleksji, opowiadań oraz częścią religijnej tożsamości społeczności, wśród której żył i nauczał prorok Ozeasz, tradycyjnie postrzegany jako postać z epoki, która była świadkiem upadku Królestwa Północnego.

\section{Punkty styczne Genesis i Ozeasza ${ }^{6}$}

Biblia Hebrajska zaczyna się od opisu stworzenia, który generalnie uważa się za dzieło powstałe w obecnym literackim kształcie w V w. przed Chr. Dla proroka Ozeasza fakt stworzenia z pewnością nie był elementem centralnym jego przesłania, które za punkt wyjścia relacji Boga z Izraelem uważało czas formowania się Narodu Przymierza w drodze przez pustynię. Jednakże szerzący się wśród mieszkańców Królestwa Północnego kult Baala, który łączył się z celebracją

4 Dokładną analizę różnych teorii odnośnie do datacji Oz przeprowadza m.in. W. Schütte, którego zdaniem „największa część księgi została zredagowana wkrótce po upadku Samarii, na terenie Judy, w gronie uchodźców z terenów Królestwa Północnego"; W. S c h ü t t e, Die Entstehung der juda-exilischen Hoseaschrift, s. 223.

5 Por. J. M. B o s, Reconsidering the Date and Provenance of the Book of Hosea: The Case for Persian-Period Yehud, Bloomsbury T\&T Clark, New York 2013.

6 Oz 1,10 - Rdz 22,17 - błogosławieństwo Abrahama; Oz 2,18 i 4,3 - Rdz 1,20-25 - stworzenie dzikich zwierząt; Oz 6,7 - Rdz 3,6 - grzech Adama; Oz 6,9 - Rdz 34, 1-31 - zniszczenie Sychem; Oz 9,6 - Rdz 47,29 - pogrzeb w Egipcie; Oz 9,14 Rdz 49,25 - błogosławieństwo piersi i łona; Oz 11,8 - Rdz 14,2 i 19 - zniszczenie miast na równinie; Oz 12,2-5 - Rdz 25,19 - 35,15 - historia Jakuba; Oz 12,12-13 Rdz 30,25 - 31,16 - owce i Jakub; Oz 13,15 - Rdz 41,2.18 - sen faraona; aluzje do tekstów Księgi Wyjścia znajdujemy m.in. w: Oz 7,13; 8,4-6; 9,10; 10,9-10; 11,1-4; 12,9-10; 13.4-6. 
stwórczej płodności tego bożka, przyczynił się do zawarcia w orędziu proroka określenia Boga jako Stwórcy. W Oz 8,14 znajdujemy sformułowanie: „Zapomniał Izrael o swoim Stworzycielu” (עשֶה), które, biorąc pod uwagę cały kontekst tego fragmentu, można interpretować jako nawiązanie nie tyle do aktu stworzenia, ale bardziej do tworzenia się narodu w procesie wyjścia z Egiptu. Autor w ten sposób nawiązywałby do obrazu Boga jako Ojca dla Izraela (Oz 2,1; 11,1), który swoje ojcostwo okazał w pełni, opiekując się narodem na pustyni.

To, co zwraca na siebie uwagę, to zbieżność zdania z Oz 8,14 z tekstem Pwt 32,15.18. Znajdujemy tam identyczne sformułowanie: wayyiškah 'et- ‘'̄śéhû - ,zapomniał Stwórcę” („Utył Jeszurun i wierzga - grubyś, tłusty, otyły. Boga, Stwórcę swego porzucił, zelżył Skałę, swoje ocalenie [...] Gardzisz Skałą, co ciebie zrodziła, zapomniałeś o Bogu, który cię zrodził”). Oba teksty zdradzają charakter indywidualnej lamentacji, wzmocnionej przez sufiksy zaimkowe dołączone do formy partycypialnej. ${ }^{7}$ Wydaje się, że zarówno prorok, jako i autor Pwt 32 korzystali z starego hymnu, który mógł być znany ich słuchaczom.

Z pewnością dla Ozeasza ważnym momentem dziejów zbawienia było wybranie narodu na pustyni i tutaj mógł on upatrywać działanie Boga jako Stwórcy, jednakże kontakty z kultami kananejskimi zmuszały także do odpowiedzi na pytania odnośnie do powstania świata i jego kreatora. Jest całkiem możliwe, że kananejski kult Ela, jako stwórcy, oraz Baala, jako tego, który dzieło Ela kontynuuje, mogły stworzyć potrzebę opracowania własnej wizji teologicznej, która ma swój wyraz w obu wyżej zaprezentowanych fragmentach. Dlatego też ów tytuł Boga jako Stwórcy może mieć także wydźwięk polemiczny w odniesieniu do problemów synkretyzmu religijnego i kultu płodności, z którymi mamy do czynienia na terenie Samarii. $Z$ drugiej jednak strony, refleksja nad stworzeniem miała również wymiar uniwersalny, pozwalający postrzegać Izrael jako jeden z ludów zamieszkujących Kanaan, z racji stworzenia należący do jednej

S. P a a s, Creation \& Judgement, s. 336. 
rodziny ludzkiej. ${ }^{8}$ Kolejne fragmenty Księgi Ozeasza podkreślają odnowione przymierze $(\mathrm{Oz} 2,18-25)$ nie tylko z ludźmi, ale i z całym stworzeniem. Znajdujemy tutaj wizję teologiczną, która ma wiele wspólnego z teologią prapoczątków zawartą w Rdz 1-11. Pozwala nam ona postrzegać Jahwe jako tego, który jest nie tylko Bogiem historii, ale również Bogiem natury i całego stworzenia.

Uniwersalizm oddziaływania przymierza jest widoczny m.in. w Oz 2,20, gdzie prorok stwierdza: „W owym dniu zawrę z nią przymierze, ze zwierzem polnym i ptactwem powietrznym, i z tym, co pełza po ziemi. Łuk, miecz i wojnę wyniszczę z jej kraju, i pozwolę jej żyć bezpiecznie" (Oz 2,20). Po raz pierwszy w swoim tekście Ozeasz używa terminu borît - ,przymierze". ${ }^{9}$ Nie jest ono tutaj określone jako nowe, ale wiersze poprzednie, opisujące grzech Izraela, obejmujący m.in. wzywanie imienia Baala przed imieniem Boga, pozwalają nam domniemywać, że zostało ono uprzednio zawarte na pustyni i potem złamane. Czyli z jednej strony nawiązanie do przymierza nakazuje zwrócić się myślą do idei Boga historii, który najpierw z Abrahamem, a następnie z całym narodem na pustyni zawarł przymierze, $z$ drugiej jednak strony, ma ono ponadhistoryczny wymiar, który nakazuje wrócić do idei prapoczątków. To przymierze, zawarte po raz kolejny, ma ten właściwy sobie rys, że jest ono jednostronne. Jego uczestnikiem ma być cały świat stworzony, podobnie jak w przypadku przymierza noachickiego, ale już bez sformułowanych jasno zobowiązań. Na uwagę zasługuje kolejność stworzeń wymienionych w Oz 2,20 (wok ārattî lāhem borît bayyôm hahû ${ }^{2}$

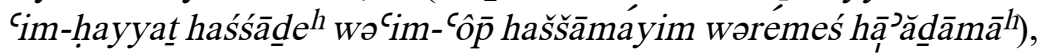
która uderzająco przypomina listę stworzeń z Rdz 1,26-30.

W Oz 2,20 prorok wymienia trzy kategorie zwierząt, które porządku, kierując się logiką miejsca ich występowania. Są to ,zwierzęta polne, ptaki na niebie i płazy na ziem”. W Oz 4,3 pojawia się

8 A. D e a r m a n, The Book of Hosea, NICOT, Eerdmans, Grand Rapids 2010, s. $41-42$.

9 Ozeasz pięć razy używa terminu borît- ,przymierze”: 6,7; 8,1; 11,1; 13,4-5 i 2,20 . 
podobna lista, z tym, że jest ona jeszcze bardziej złożona: ,zwierzęta polne, ptaki na niebie i ryby morskie". Pojawia się tu ona w celu zobrazowania obszarów, które są dotknięte skutkami grzechu człowieka i złamania przez niego przymierza. Grzech niszczy harmonię stworzenia, co widzimy już w Rdz 3. Co ciekawe, prorok włącza tutaj również ryby morskie jako istoty współuczestniczące w ponoszeniu skutków grzechu, co pokazuje konsekwencje jeszcze dalej idące niż w przypadku potopu, gdzie ryby miały się raczej dobrze. Tekst z Oz 4,3 znajduje się na początku kolejnej części tej księgi (Oz 4,1 9,9), która zawiera oskarżenie skierowane przede wszystkim wobec przywódców religijnych i politycznych. Jako pierwsi są wymienieni kapłani, jako osoby odpowiedzialne za stan moralny i duchowy powierzonej im społeczności. Lista grzechów wymienionych przez proroka w Oz 4,2 wydaje się mieć wiele wspólnego z występkami opisanymi w prehistorii biblijnej, między którymi najbardziej godne potępienia jest przelewanie krwi. Lista wymienionych grzechów w Oz 4,2 nie nawiązuje do zagadnień kultycznych, które można wiązać z jedną wybraną społecznością, ale mają one bardziej uniwersalny charakter, wynikający z faktu stworzenia. Lim w swoim komentarzu widzi tutaj aluzję do przelanej krwi Abla oraz do zakazu przelewania ludzkiej krwi skierowanego do ocalałej z potopu ludzkości. ${ }^{10}$

10 Bo H. L i m, D. C a s t e 11 o, Hosea, Eerdmans, Grand Rapids 2015, s. 116-118; por. M. D e R o c h e, The Reversal of Creation in Hosea, VT 31 (1981) 4, s. 400-409. W Rdz mamy do czynienia z czterema grupami zwierząt (u Ozeasza brakuje ryb i środowiska wodnego), natomiast prorok prezentuje je w trzech grupach, identycznie jak w Rdz 1,30. „Dlatego kraj jest okryty żałobą i więdną wszyscy jego mieszkańcy, zarówno zwierz polny, jak ptactwo powietrzne, a nawet ryby morskie marnieją. (Oz 4,3) W owym dniu zawrę z nią przymierze, ze zwierzem polnym i ptactwem powietrznym, i z tym, co pełza po ziemi. Łuk, miecz i wojnę wyniszczę z jej kraju, i pozwolę jej żyć bezpiecznie" (Oz 2,20). To, co można określić jako kolejny punkt styczny między opowiadaniem o stworzeniu i opis skutków przymierza u Oz, to wpływ człowieka i jego postawy na świat stworzony. Stworzenie nie jest samoistnym przypadkowym tworem, ale jest skierowane na człowieka i dzieli z nim los. Wydaje się, że można zauważyć tę wspólnotę losów również w historii potopu $(\operatorname{Rdz} 6,1-9,17)$. Kończy się ona zawarciem przymierza nie tylko z ocalałymi ludźmi, ale także z całym stworzeniem. Pojawia się również 
Pewne wspólne motywy skutków grzechu w Rdz 3,18 i Oz 10,8 są zauważalne w wyrażeniu ,ciernie i osty” (qôs wọdardar Oz 10,8; por. Hbr 6,8), które według proroka mają wyrosnąć na ołtarzach na wyżynach. Ten tekst ukazuje skutki ,ekologiczne” ludzkiego grzechu. Ze względu na fakt, że ów zwrot pojawia się w tej formie jedynie w tych dwóch fragmentach, można zadać pytanie odnośnie do tego, czy prorok celowo szukał tutaj takiego nawiązania, czy też jest to przypadkowa zbieżność. Zdaniem Dearmana, znajdujemy tutaj celowe odniesienie do słów Stwórcy wypowiedzianych do pierwszych ludzi w celu wzmocnienia negatywnej oceny wznoszonych wyżyn i ołtarzy na terytorium Królestwa Północnego. ${ }^{11}$ Pozostaje otwarte pytanie odnośnie do tego, czy Ozeasz mógł znać tradycję związaną z opowiadaniem o grzechu pierwszych ludzi (Rdz 3). Być może w Oz 6,7 znajdujemy nawiązanie do grzechu Adama i do pierwszego zawartego z nim przymierza (,Ale już w Adam złamali przymierze i niewiernymi się tam okazali”). ${ }^{12} \mathrm{~W}$ polskim tłumaczeniu ta więź obu motywów została pominięta, gdyż w Biblii Tysiąclecia

obietnica, że potop nigdy się nie powtórzy, a stworzenie nigdy nie ulegnie więcej zagładzie. Pojawia się tutaj, podobnie jak w Oz 2,21 motyw przymierza zawartego „na wieki” (10`ôlām Oz 2,21), podobnie jak w przypadku Noego Rdz 9,8-17 (Rdz 9,10 szczególnie przypomina obietnice z Oz): „Potem Bóg tak rzekł do Noego i do jego synów: «Ja, Ja zawieram przymierze $\mathrm{z}$ wami i z waszym potomstwem, które po was będzie; z wszelką istotą żywą, która jest z wami: z ptactwem, ze zwierzętami domowymi i polnymi, jakie są przy was, ze wszystkimi, które wyszły z arki, z wszelkim zwierzęciem na ziemi. Zawieram z wami przymierze, tak iż nigdy już nie zostanie zgładzona wodami potopu żadna istota żywa i już nigdy nie będzie potopu niszczącego ziemię»" ( $\mathrm{Rdz}$ 9,8-11).

11 A. D e a r m a n, The Book of Hosea, s. 267.

12 Szczegółowo analizuje ten fragment W. Gisin, którego zdaniem cały fragment Oz 6,7-11a ma swoje odniesienia do Rdz: „Hos 6,7 is an allusion on the sin of Adam and Eve (Gen 3); 6,8 on Gilead, which was »betrayed by«the menstruation »blood «of Rachel (Gen 31); 6,9 on the Shechem episode, where Dina had premarital sex (Gen 34); 6,10 is the summary of 6,7-9; and 6,11a is formulated on the basis of Eve's etiology on the name of Seth (Gen 4,25) to make an allusion on Judah's sexual relationship with Tamar, the «harvest» being the twins whom she bore him (Gen 38)"; W. G i s i n, Adam, Eva und die Jakobsfamilie in Hosea 6,7-11a, w: S. R i e c k e r, J. S t e i n b e r g (red.), Das heilige Herz der Tora. Festschrift für Hendrik 


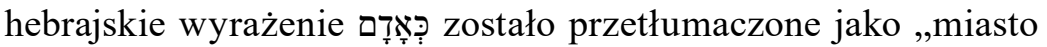
Adama" (podobnie tłumaczenie Paulistów), natomiast tekst grecki tłumaczy bardzo dosłownie, chociaż nie używa imienia pierw-

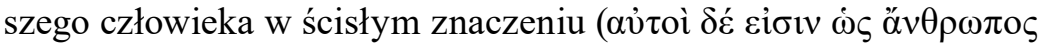

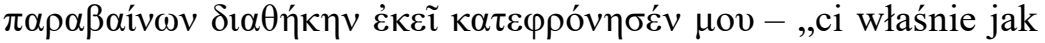
człowiek przekroczyli przymierze i zdradzili mnie"; Oz 6,7). Stwier-

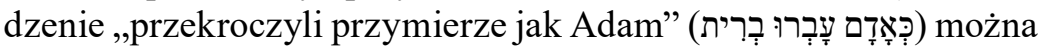
traktować jako aluzję do opisu grzechu w Rdz 3 i do przymierza zawartego między Bogiem a ludzkością z racji aktu stworzenia. Można to postrzegać jako ukazanie skutków grzechu Adama, który jako pierwszy człowiek łączy losy poszczególnych ludów przez wspólną skłonność do sprzeciwiania się Bogu (w tym duchu interpretują ów tekst Rashi i autorzy targumicznej wersji tekstu oraz Wulgata). ${ }^{13} \mathrm{Wy}-$ daje się jednak, że byłoby słuszniej umieścić tekst Oz 6,7 bardziej w kontekście przymierza zawartego przez Mojżesza na pustyni. Kolejne wiersze w tekście masoreckim (Ozeasz w ww. 6,8-9 wymienia Gilead, Sychem, Betel) sugerują raczej interpretację idącą w kierunku rozumienia tego wyrażenia $\mathrm{w}$ sensie geograficznym. ${ }^{14}$

Koorevaar zu seinem 65. Geburtstag, Theologische Studien, Shaker Verlag, Aachen 2011, s. 61.

13 A. M a c in to s h, A Critical and Exegetical Commentary on Hosea, T\&T Clark, Edinburgh, 1997, s. 236.

14 Por. A. D e a r m a n, The Book of Hosea, s. 198. Zdaniem Macintosha, może ów tekst interpretować dwojako. Z jednej strony, idąc w kierunku interpretacji politycznej, złamanie przymierza, oznaczałoby nawiązanie do wybuchu rebelii Peqacha (735 przed Chr.) i wojny syroefraimskiej, która mogła się zacząć w mieście Adam w Gileadzie. Wojna przeciwko Judzie była złamaniem wcześniej zawartego przymierza między królestwami Judy i Samarii. Jahwe, będąc gwarantem przymierza, został w ten sposób zlekceważony. Druga możliwa interpretacja zmierzałaby w kierunku intencjonalnego nawiązania do przymierza zawartego między Bogiem a człowiekiem, bez precyzowania i dokładnego określenia o jakie przymierze tu chodzi; A. M a c in t o s h, A Critical and Exegetical Commentary on Hosea, s. 238-239; por. W. M i c h n i e w i c z, ,Jeżeli nie uwierzycie, nie ostoicie się” (Iz 7,9), czyli o wojnie syro-efraimskiej, Studia Teologiczne Białystok, Drohiczyn, Łomża 25/2007, s. 5-20. 
Kolejnym punktem wspólnym między historią patriarchów a Księgą Ozeasza jest charakterystyczne stwierdzenie ,jak piasek morski". W Oz 2,1 (TM) znajdujemy zdanie, które bardzo przypomina słowa skierowane do Abrahama i Jakuba („Liczba synów Izraela będzie jak piasek nadmorski, którego nie można zmierzyć i nie można zliczyć. A zamiast ich nazywać: «Lud nie mój», będą im mówić: «Dzieci żyjącego Boga»" (Oz 2,1). Sformułowanie ,,jak piasek nadmorski” jest przysłowiowym określeniem obfitości i bogactwa. Znajdujemy je w Rdz 32,13, gdzie wypowiada je Jakub cytujący obietnice dane przez Boga. Wcześniej jeszcze możemy je odnaleźć w Rdz 22,17 (,Będę ci błogosławił i dam ci potomstwo tak liczne jak gwiazdy na niebie i jak ziarnka piasku na wybrzeżu morza") w odniesieniu do Abrahama (podobnie w Rdz 41,49; Joz 11,4; Sdz 7,12; 1Sm 13,5; 1Krl 4,20). ${ }^{15}$ Jest to określenie, które pojawia się najczęściej w kontekście przymierza i obietnic danych patriarchom. Dodatkowo, odnośnie do Abrahama pojawia się określenie ,jak gwiazdy na niebie” ( $R d z 15,5$; 26,4 w odniesieniu do Izaaka), czego brakuje np. odnośnie do Jakuba i czego nie ma u Ozeasza.

Wydaje się, że z uwagi na fakt, iż w Księdze Ozeasza widać bardzo wyraźną znajomość tradycji o Jakubie, to być może właśnie z tego źródła zastało to stwierdzenie zaczerpnięte. Podobne sformułowanie odnoszące się do licznego potomstwa znajdujemy w Rdz 28,14, gdzie w czasie teofanii w Betel, padają słowa mówiące o potomstwie tak licznym ,,jak proch ziemi”. Pewnych analogii można się doszukiwać w zdaniu z 1Krl 4,20 gdzie narrator stwierdza: „Juda oraz Izrael byli liczni jak piasek nadmorski. Jedli, pili i weselili się". Mamy w tym zdaniu nawiązanie do czasów Salomona, gdy dwa kraje były zjednoczone pod jednym berłem i wokół wspólnej wiary. Tym bardziej ten kontekst jest możliwy z uwagi na to, że w Oz 2,2 mamy zapowiedź mówiącą o ponownym zjednoczeniu dwóch królestw. Dlatego jest prawdopodobne, że bardziej właściwym odniesieniem dla tego sformułowania u Ozeasza nie są obietnice dane patriarchom,

15 Por. E. I. A n derse n, D. N. Free d m a n, Hosea, AB, Doubleday, New York 1980, s. 202. 
ale epoka zjednoczonego królestwa w czasach Dawida i Salomona. Zdaniem Dearmana, oba konteksty są równouprawnione do brania ich pod uwagę. ${ }^{16} \mathrm{Z}$ kolei Ska uważa, że zdania określane jako „discorsi divini”, zawierające m.in. sformułowania o ,potomstwie licznym jak proch ziemi” itp., należą do elementów, które najpóźniej zostały wprowadzone do tekstu Księgi Rodzaju (po powrocie z wygnania babilońskiego), a ich zadaniem było połączenie początkowo niezależnych cyklów o patriarchach w jeden zwarty tekst. ${ }^{17}$ Można więc dedukować, że ów zwrot pojawiający się u Ozeasza być może jest bardziej pierwotny w stosunku do tej części tekstu Księgi Rodzaju, w której znajdują się obietnice licznego potomstwa.

Kolejne teksty dosyć jednoznacznie odwołujące się do różnych fragmentów Księgi Rodzaju to m.in. nawiązanie do zniszczenia Seboim i Admy (Oz 11,8: ,Jakże cię mogę porzucić, Efraimie, i jak opuścić ciebie, Izraelu? Jakże cię mogę równać z Admą i uczynić podobnym do Seboim? Moje serce na to się wzdryga i rozpalają się moje wnętrzności”, por. Rdz 19,24-29 i Pwt 29,22). Jak się wydaje, tradycja o kataklizmie, który zniszczył pewne miasta $\mathrm{w}$ okolicach Morza Martwego, ma swoje przedmonarchiczne pochodzenie. Natomiast samo odniesienie do tych miast było obiegowym i przysłowiowym wyrażeniem, mającym na celu podkreślenie, że coś jest groźne, całkowite i nieodwołalne. ${ }^{18}$ Nasz prorok nie wymienia Sodomy i Gomory, tak jak mamy to w przypadku Rdz 10,9; 14,8. Także kontekst zniszczenia jest inny. Według Księgi Rodzaju powodem były nadużycia moralne, natomiast według proroka powodem zniszczenia jest brak nawrócenia i rezygnacja z pielęgnowania synowskich relacji z Bogiem - Ojcem. Prorok, opisując sytuację Efraima oraz הפךקeakcję Boga na niewierność swojego ludu, stosuje czasownik

16 Por. A. D e a r m a n, The Book of Hosea, s. 104.

17 Por. J. L. S k a, Introduzione alla lettura del Pentateuco. Chiavi per l'interpretazione dei primi cinque libri della Bibbia, Edizioni Dehoniani, Bologna 2000, s. 116-117, 123-128; por. J. L e m ań s k i, Księga Rodzaju, NKB I/2, Święty Paweł, Częstochowa 2014, s. 500-502.

18 W. W. F i e l d s, Sodom and Gomorrah. History and Motif in Biblical Narrative, Academic Press, Sheffield 1997, s. 165. 
(Oz 11,8) - ,zniszczyć”, „odwracać”, ,zmienić”. Warto zauważyć, że identyczne słowo pojawia się w Rdz 19,21.25.29 i w Pwt 29, gdzie te miasta są także wymienione i gdzie jest ono użyte w opisie zniszczenia. ${ }^{19}$ Może to wskazywać na literalną zależność tych tekstów od siebie, z tym że Ozeasz stosuje to wyrażenie w zupełnie innej

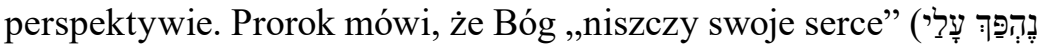
לִ?ִ Oz 11,8) z miłości i litości do swego dziecka. Zamiast obrócić w ruinę Efraima, Bóg woli sam wyniszczyć siebie. Zdaniem niektórych, jest to fragment, który można określić mianem „Ewangelii Starego Testamentu". ${ }^{20}$ Jest to wyraz działania Boga, który, rezygnując z kary, ma na celu przede wszystkim ocalenie człowieka i podkreśla to w stwierdzeniu pojawiającym się w Rdz 18,25 i Oz 11,9, że: „Jestem Bogiem a nie człowiekiem". ${ }^{21}$

\section{Cykl Jakuba w Księdze Ozeasza}

Wydaje się, że najszerzej prezentowanym wspólnym motywem Rdz 25-35 i Oz 12 jest postać patriarchy Jakuba. Znajdujemy mnóstwo szczegółów mówiących o tym, że istnieje ścisła więź między tradycją o Jakubie przekazaną Księdze Rodzaju a tradycją uwidocznioną w Księdze Ozeasza, z tym że ocena tej postaci jest w obu tekstach odmienna. Prorok podkreśla niestabilność i kłótliwy charakter protoplasty Izraelitów, który jest jednocześnie elastyczny i potrafiący na zawołanie płakać i błagać o litość. Zdaniem proroka, jest on bardziej chytry niż fałszujący wagę fenicki handlarz. W Oz 12,12-13 widoczny jest punkt zwrotny, który pozwala skonfrontować ze sobą

19 „Odpowiedział mu: «Przychylam się i do tej twojej prośby; nie zniszczę

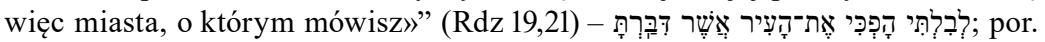
J. A. L o a d e r, The prophets and Sodom: The prophetic use of the Sodom and Gomorrah Theme, HTS 47 (1991) 1, s. 11-12.

${ }^{20}$ Te n ż e, A Tale of Two Cities: Sodom and Gomorrah in the Old Testament, Early Jewish and Early Christian Traditions, CBET 1, J. H. Kok Publishing House, Kampen 1990, s. 68.

${ }^{21}$ Por. t e n ż e, The prophets and Sodom, s. 12. 
Jakuba i bezimiennego proroka, który prowadził lud przez pustynię. ${ }^{22}$ Zdaniem Pury'ego, prorokowi chodzi w tym miejscu o konfrontację dwóch źródeł tożsamości dla Izraela. Jedno źródło tożsamości to utożsamienie się z rodem, z fizycznym pochodzeniem z konkretnego szczepu, z konkretnej matki, które pozwala się identyfikować z określonym środowiskiem. Druga koncepcja, pochwalona przez proroka, nakazuje szukać swojej tożsamości w powołaniu prorockim, w charyzmacie, który przekracza granice biologiczne, genetyczne i społeczne, a jednocześnie pozwala łączyć w jednej wspólnocie różne środowiska. Prawdziwym przodkiem dla Ozeasza jest więc prorok, nie Jakub, którego paradoksalnie kobieta z Aramu czyni ojcem i patriarchą. Na tym etapie nie widać absolutnie dziejów zbawienia z perspektywy Pięcioksięgu, gdzie historia patriarchów i wyjście tworzą jedną, w miarę spójną historię, która wzajemnie się uzupełnia. W wersji dziejów prezentowanej u Ozeasza są one sobie przeciwstawione. $^{23}$

Pewnie nigdy nie zostanie rozwiązana do końca kwestia wzajemnej relacji między opowiadaniem o Jakubie obecnym w Rdz 25-35 i w Księdze Ozeasza. ${ }^{24}$ Dla części badaczy jest jasne, że pochodzą one z wspólnego źródła, dla innych to tekst Ozeasza dostarczył wielu

22 „Jakub uszedł na pola Aramu, Izrael dla kobiety oddał się na służbę i dla kobiety stał się stróżem stada - lecz Pan wyprowadził Izraela z Egiptu przez proroka, i również przez proroka otoczył go opieką" (Oz 12, 13-14)

${ }^{23}$ Por. A. d e P u r y, The Jacob story and the beginning of the formation of the Pentateuch, w: T. B. D o z e m a n, K. S c h m id (red.), A farewell to the Yahwist? The composition of the Pentateuch in recent European interpretation, Brill, Leiden 2006, s. 60: „No other biblical passage illustrates it more clearly: the Jacob story and the Moses story originally represent not two consecutive chapters in Israel's history but two rival legends of Israel's origins! The poem of Hos 12 as a whole must be understood as a plea for the legitimate legend, for the right ancestor, for Israel's true identity: in other words, Israel is invited to choose its ancestor".

24 E. B 1 u m, Hosea 12 und die Pentateuchüberlieferungen, w: C. A n s e $1 \mathrm{~m}$ (red.), Die Erzväter in der biblischen Tradition, FS M. Köckert, de Gruyter, Berlin 2009, s. 313: „Hosea den Zusammenhang der Jakobserzählung nicht nur kannte, sondern diese Kenntnis auch bei seinen Lesern/Hörern in einer Selbstverständlichkeit voraussetzen konnte, die es ihm erlaubte, den Plot (der Jakobserzählung) 
motywów powygnaniowym redaktorom $\mathrm{Rdz} 25-35$, o ile uwzględni się bardzo wczesną kompozycję Oz 12, jak chce Macintosh i wielu innych.

Według Andersena i Freedmana, wspólne słownictwo tworzy bazę w celu ukazania wzajemnych literackich zależności. Szczególnie termin (Oַּ 12,5) - ,przezwyciężył”, ,zwyciężył” - identyczny jak w Rdz 32,29, zdaniem wielu czyni zależność obu tekstów niepodważalną ${ }^{25}$. Z kolei W. Whitt uważa, że to tekst Księgi Rodzaju jest zależny od Ozeasza; m.in. notuje, że motyw dwóch żon Jakuba wynika z błędnego odczytania Oz 12,13b, gdzie mamy słowo „kobieta” powtórzone dwukrotnie (,,Jakub uszedł na pola Aramu, Izrael dla k obi ety oddał się na służbę i dla k o bi ety stał się stróżem stada"). Jego zdaniem, przyczyniło się to do rozbudowania motywu Racheli i Lei w Księdze Rodzaju. ${ }^{26}$

Bos, skupiając się na powiązaniu postaci Jakuba z Betel, sytuuje czas powstania tego fragmentu Księgi Ozeaszana VI w. przed Chr., ponieważ charakteryzuje go polemiczne nastawieniem do tego ośrodka, odwrotnie niż np. Rdz 28. ${ }^{27}$ Widać to m.in. w przedstawieniu reform Jozjasza w 2Krl 25,15-19, gdzie znajdujemy opis zniszczenia miejsca kultu oraz szczątków uprzednich mieszkańców Betel. Podobną linię podejmuje Römer i Nissinen. Natomiast zdaniem Pury'ego fakt, że w Oz 12,lb jest wzmianka o mieszkańcach Judy ukazanych jako idealni wyznawcy Jahwe („Efraim otoczył Mnie kłamstwem,

in nahezu beliebigen Arrangements aufzunehmen, ihn provozierend «gegen den Strich zu bürsten» oder sich auch mit subkutanen Anklängen zu begnügen“.

25 Por. E. I. A n d e r s e n, D. N. Fre e d m a n, Hosea, s. 608; por. S. L. M c K e n z i e, The Jacob Tradition in Hosea XII 4-5, VT 36/1986, s. 314-316. Zdaniem Dziadosza, miejscem utrwalania tradycji o Jakubie było Betel, które miało uniknąć wielkich zniszczeń materialnych związanych z upadkiem Samarii w 722 r. przed Chr.; D. D z i a d o s z, Geneza biblijnych tradycji o patriarchach w Rdz 12-36, w: t e n ż e, Tak było na początku... Izrael opowiada swoje dzieje. Literacka i teologiczna analiza wiodacych tradycji Księgi Rodzaju, Przemyśl 2011, s. 311-313.

26 W. D. W h i t t, The Jacob Traditions in Hosea and their Relation to Genesis, ZAW 103/1991, s. 18-43.

27 Por. J. M. B o s, Reconsidering the Date, s. 159-162. 
oszustwem - dom Izraela, lecz Juda zna jeszcze Boga i nazywa się ludem Świętego"; Oz 12,1), dowodzi wczesnej reinterpretacji tekstu Ozeasza w judzkim środowisku, który został w ten sposób, w okresie przed wygnaniem zamknięty. Lapidarność odniesień do poszczególnych epizodów związanych z Jakubem oraz brak chronologicznego porządku przedstawianych faktów świadczy o tym, że opowiadanie krążyło w ustnej, poetyckiej tradycji. Pozwalało to Ozeaszowi na krótkie nawiązania do poszczególnych etapów dziejów Jakuba, które musiały być szerzej znane słuchaczom proroka. ${ }^{28}$

Z pewnością uderza wielka liczba wspólnych elementów odnośnie do Jakuba, które znajdujemy w Oz 12 i Rdz 25-36: ${ }^{29}$ bliźniacze narodziny (Oz 12,4a i Rdz 25,21-26), wspólna etymologia imienia Jakub (w. 4a i Rdz 25,26; 27,36, pojawia się w obu przypadkach ten sam rdzeń שרה -,walczyć”, ,rywalizować” - który u Ozeasza występuje tylko raz). Jakub uprzedza swego brata, chwytając się jego pięty (4a i Rdz 25,21-26. 29-34; 27,1-45), również w obu historiach walczy z Bogiem lub jego aniołem (w. 4b i Rdz 32,23-33). Oba teksty podają etymologię imienia Izrael (w. 5a i Rdz 32,19), oraz ukazują niejednoznaczne zwycięstwo patriarchy w nocnym zmaganiu (w. 5a i Rdz 32,27.30-31). W obu tekstach pojawia się opis spotkania w Betel

28 Por. A. d e P u r y, The Jacob Story, s. 62. Negatywna ocena postaci Jakuba i jego spadkobierców, jest być może próbą odpowiedzi na pytanie o przyczynę klęski, jaka spotkała mieszkańców Królestwa Północnego; por. D. D z i a d o s z, Geneza biblijnych tradycji o patriarchach $w$ Rdz 12-36, s. 311-313. Jest możliwe, że taki obraz Jakuba wynika z pewnego etapu redakcji w kręgu tradycji Dtr, która także unika prezentowania tej postaci. Widać pewne napięcie w podejściu do prezentowania korzeni tożsamości Izraela. jednym z przejawów tego napięcia jest formuła starożytnego wyznania wiary, gdzie widoczne jest poczucie przynależności do szerszej społeczności niż sam Izrael: „Ojciec mój, Aramejczyk błądzący, zstąpił do Egiptu..." (Pwt 26,5). Przodek narodu był więc Aramejczykiem, nie zaś Izraelitą. Naród Izraela narodził się w Egipcie, pod wodzą Mojżesza-proroka, nie wcześniej; por. te n ż e, Walka Jakuba z Bogiem (Rdz 32,23-33), w: t e n ż e, Tak byto na poczatku... Izrael opowiada swoje dzieje. Literacka i teologiczna analiza wiodacych tradycji Księgi Rodzaju, Przemyśl 2011 s. 457.

29 Por. C. J. S. L o m b a a r d, Jacob come lately? Hosea 12 and the Problem of Dating the Patriarchs of Ancient Israel, Scriptura 113 (2014) 1, s. 1-9. 
(w. 5b i Rdz 28, 10-22; 35,1.7), obietnica opieki i bezpiecznego powrotu (w. 7 i Rdz 28,15; 31,13), ale również ukazanie nabycia bogactwa za pomocą środków wątpliwych moralnie (w. 9 i Rdz 30,25-31,19). Zaprezentowana jest ucieczka do Aramu (w. 13a i Rdz 27,43-45; 29,1) oraz wspomnienie o wzniesieniu kamiennego stosu w Gileadzie (w. 12b i Rdz 31,46-54), dobrowolna służba w celu zapracowania na małżonkę (w. 13b i Rdz 29,15-30), która w obu tekstach jest ukazana jako pasterstwo (w. 13b i Rdz 30,25-42). Jakub wydaje się postacią negatywnie ukazaną u Ozeasza, w przeciwieństwie do cyklu Jakuba w Księdze Rodzaju, gdzie dominuje obraz bardzo pozytywny, aczkolwiek nie wolny od ukazania patriarchy wraz z jego przywarami i nie do końca czystymi rękoma. ${ }^{30}$

\section{Tradycja Wyjścia}

Na uwagę zasługuje wspólna dla Ozeasza i redaktorów Księgi Wyjścia i Księgi Powtórzonego Prawa tradycja wyprowadzenia Izraelitów z Egiptu. ${ }^{31}$ Została ona ukazana w prologu do Dekalogu, gdzie służy podkreśleniu zbawczej inicjatywy Boga, który swoim działaniem uprzedza odpowiedź człowieka na Jego akt zbawczy. Jest to wspólna idea proroka Ozeasza i redaktorów Dekalogu. Natomiast warto zauważyć odmienne słownictwo opisujące wyprowadzenie z Egiptu, które pojawia się w jednym i drugim przypadku. Ozeasz używa terminu ,wchodzenie” (Oz 2,17; 12, 14 - עלה), podczas gdy

30 Por. A. L e vi n, A new context for Jacob in Genesis and Hosea 12, w: J. R. W o o d i in. (red.), From Babel to Babylon. Essays on Biblical History and Literature in Honour of Brian Peckham, T\&T Clark, New York 2006, s. 226-236.

31 T. B. D o z e ma n, Hosea and the Wilderness Wandering Tradition, w: T. Rö m e r, S. M c K e n z i e (red.), Rethinking the Foundations: Historiography in the Ancient World and in the Bible, de Gruyter, Berlin 2000, s. 55-70; por. K. S c h m i d, Genesis and Exodus as Two Formerly Independent Traditions of Origins for Ancient Israel, Biblica 93/2012, s. 187-208. 
wprowadzenie Dekalogu Wj 20,2 i Pwt 5,6 stosuje czasownik ,wyprowadzenie" (יצא). ${ }^{32}$

Ozeasz pomija w swojej refleksji historycznej motyw Synaju i opisy niewierności na pustyni. Podobnie jak Pentateuch uznaje, że Egipt jest tym miejscem, gdzie zaczyna się właściwa historia narodu i jego narodziny. ${ }^{33}$ Jest to również miejsce, w którym Bóg objawia siebie jako Jahwe. Sześć razy prorok nawiązuje do pustyni (Oz 2,3. $14-15 ; 9,10 ; 13,5.15)$, jednak dla niego jest ona czasem, gdy Izrael był pozbawiony ziemi i własności. Brakuje precyzyjnego sformułowania, że czas pustyni, to czas wędrówki od - do. ${ }^{34}$ Część autorów jest zdania, że mimo różnic widać wręcz zależność literacką między Pentateuchem a Ozeaszem w kwestii tradycji przebywania Izraela na pustyni, ${ }^{35}$ natomiast to, co różni, to opinia odnośnie do oceny tego, jaki charakter miał ten okresu $\mathrm{w}$ historii narodu. ${ }^{36}$

32 W historii wyjścia i pobytu na pustyni opisanych w bloku ksiąg Wj-Lb, Ska wyróżnia kilka pierwotnie niezależnych od siebie opowiadań: wyjście z Egipt (Wj 1-2; 5; 7-12; 14-15), opowiadania o pobycie pod Synajem (Wj 19; 24; 32-34), dekalog (Wj 20, 1-19); kodeks przymierza (Wj 21-23); opowiadanie o pobycie na pustyni (Wj 15; 17-18; Lb 11-14; 20-21; 25), historia Balaama (Lb 22-24).

33 Por. W. P i k or, Prorocka interpretacja exodusu, I: Amos, Ozeasz, Biblica et Patristica Thorunensia 7 (2014) 3, s. 41-53.

34 Por. J. L e m a ń s k i, Exodus - pomiędzy historią, mitem i koncepcją teologiczna, BibAn 4/2014, s. 279-311.

35 Por. J. M. B o s, Reconsidering the Date, s. 158. Ten autor zasadniczo optuje za dosyć późną redakcją Księgi Ozeasza. Widząc w niej dzieło w większej części powstałe w epoce perskiej, nie neguje obecności w niej bardzo starych tradycji. Do nich zalicza refleksję nad pobytem Izraela na pustyni.

36 T. D o z e m a n, Wilderness Wandering, s. 70. Analizując pierwsze słowa Dekalogu, zauważa dwa konstytutywne elementy powiązane $\mathrm{z}$ historią wyjścia podstawowa forma formuły: „Ja jestem Jahwe”, zostaje rozbudowana o dwa elementy: pierwszy - „twój Bóg” - przywołuje jeden z elementów formuły wzajemnej przynależności opisującej relację przymierza, drugi natomiast - „od ziemi egipskiej”- wskazuje na czas zawiązania tej relacji. H. W. Wolff uznaje przywołaną przez Ozeasza formułę (,,ja jestem dla nich Bogiem”) za „część pierwotnego creda Izraela"; H. W. W olf f, Hosea. A Commentary on the Book of the Prophet Hosea, Hermeneia, Philadelphia 1974 s. 197; Według Pikora, prorokowi znana jest m.in. historia zamieszkiwania w namiotach. W Oz 12,10 znajdujemy zdanie: „Jam jest 
U Ozeasza widoczna jest odmienna ocena okresu pobytu na pustyni aniżeli w tradycjach Pięcioksięgu. Przede wszystkim okres pustyni jest przedstawiany u proroka jako czas harmonii między Bogiem a narodem wybranym. Bunty są prezentowane jako stan związany z czasem pobytu w już zagospodarowanym kraju. Perspektywa Pentateuchu jest zasadniczo inna. Pustynia jest czasem buntu, kryzysów wiary i miejscem oczyszczenia. Jedyny negatywny epizod, do którego nawiązuje prorok i który wydaje się być szerzej znany w jego środowisku, to tradycja buntu i intymnych relacji z kobietami z Madian, który to incydent jest lokalizowany pod Baal Peor. Prorok w Księdze Ozeasza 9,10 nawiązuje do zdarzenia opisywanego w Pwt 4,3 i Lb 25,1-5: ${ }^{37}$ „Jak winne grona na pustyni, tak Izraela znalazłem; jak na pierwszy owoc figowego drzewa na waszych przodków patrzyłem: lecz przyszli do Baal-Peor i oddali się hańbie, i stali się wstrętni jak to, co kochali’. Autorzy zwracają uwagę na różnice leksykalne między tekstami. Szczególnie wyraźnie widać brak u Ozeasza w tym kontekście tak preferowanego przez niego czasownika

Pan, Bóg twój, od ziemi egipskiej, dozwolę ci jeszcze zamieszkać w namiotach, jak było za dni Spotkania". Widoczna jest u proroka bardzo żywa pamięć odnośnie do okresu pustyni. Warto na to zwrócić uwagę, bo Ozeasz naucza w okresie intensywnego rozwoju Królestwa Północnego, które okrzepło mocno za czasów Jeroboama II. Powrót do okresu pustyni jest zapowiedziany jako czas odnowy, a nie kary; W. P i k o r, Prorocka interpretacja exodusu, s. 48-52.

37 Lb 25,1-9: ,Gdy przebywali w Szittim, zaczął lud uprawiać nierząd z Moabitkami. One to nakłaniały lud do brania udziału w ofiarach składanych ich bożkom. Lud spożywał dary ofiarne i oddawał pokłon ich bogom. Izrael przylgnął do Baal-Peora, i gniew Pana zapłonął przeciw niemu. I rzekł Pan do Mojżesza: «Zbierz wszystkich winnych przywódców ludu i powieś ich dla Pana wprost słońca, a wtedy odwróci się zapalczywość gniewu Pana od Izraela». Rozkazał więc Mojżesz sędziom Izraela: «Zabijajcie każdego z waszych ludzi, którzy się przyłączyli do Baal-Peora». I oto przybył jeden z Izraelitów i przyprowadził Madianitkę do swoich braci przed oczami Mojżesza i całego zgromadzenia Izraelitów, którzy lamentowali u wejścia do Namiotu Spotkania. Ujrzawszy to kapłan Pinchas, syn Eleazara, syna Aarona, chwycił w rękę włócznię, opuścił zgromadzenie, poszedł za Izraelitą do komory namiotu i przebił ich obydwoje, mężczyznę Izraelitę i kobietę - przez jej łono. I ustała plaga wśród Izraelitów. Zginęło ich wtedy dwadzieścia cztery tysiące". 
- זנה - uprawiać nierząd”, który w innych miejscach jest często przez niego stosowany i który pojawia się w opisie z Lb 25,1. Nie występuje również sformułowanie צמד -,,przylgnąć”, które opisuje relację Izraelitów z bożkami (nie pojawia się ono wcale w Księdze Ozeasza). W Oz 9,10 zastosowany jest czasownik נזר, który oznacza,,poświęcić się”, „oddać cześć”, ,ślubować”. Nie jest więc widoczna ścisła leksykalna zależność między oboma tekstami, ale zdecydowanie widać wspólną tradycję. Wybrzmiewa ona również w Oz 11,2 gdzie prorok nawiązuje do incydentów mających miejsce po wyjściu z Egiptu: „Miłowałem Izraela, gdy jeszcze był dzieckiem, i syna swego wezwałem z Egiptu. Im bardziej i c h w z y w a ł e m [wzywały?], tym dalej odchodzili ode Mnie, a składali ofiary Baalom i bożkom palili kadzidła". Nie do końca jasne jest sformułowanie z Oz 11,2, które jest przetłumaczone w Biblii Tysiąclecia zgodnie z tekstem LXX, gdzie

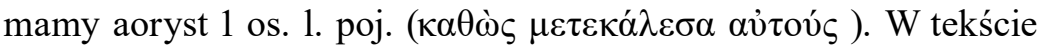

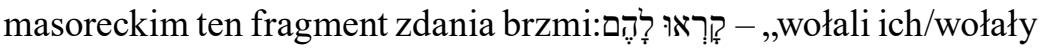
ich”, a nie ,wołałem ich”. Wydaje się, że mamy tutaj do czynienia z aluzją do kobiet z Madian (Lb 25), które miały uwieść izraelitów i skłonić ich do czci Baala. Logika tego wersu jednoznacznie na to wskazuje. ${ }^{38}$ Inaczej uważa Bodreau, który w swoim studium poświęconym incydentowi w Baal Peor (on identyfikuje to określenie przede wszystkim jako miejsce na wschód od Jordanu, na przeciw Gilgal), wymienia mnóstwo niezgodności między obiema wzmiankami. Jako główny zarzut stawia odmienne słownictwo zastosowane w obu opisach. Zauważa, że prorok nie poświęca zbyt wiele uwagi kwestii relacji z kobietami z innych narodów, chociaż wydaje się, że wspomniany wielokrotnie nierząd można podciągnąć pod tę kategorię. Poza tym u Ozeasza brakuje wzmianki o karze, która w świetle Lb 25 spadła na dopuszczających się tych czynów. Dodatkowo autor zauważa brak powiązania Mojżesza z tymi wydarzeniami. ${ }^{39}$ Mojżesz jest u Ozeasza dość enigmatycznie określony jako bezimienny prorok,

38 Por. J. M. B o s, Reconsidering the Date, s. 155-158.

39 Por. G. R. B o u d r e a u, Hosea and the Pentateuchal Traditions. The Case of the Baal of Peor, w: M. P. G r a h a m (red.), History and Interpretation. Essays 
który prowadził lud przez pustynię. ${ }^{40}$ Fakt egipskiej metryki Izraela, kultywowany szczególnie w Królestwie Północnym, stwierdza van Seters, który notuje m.in., że Ozeasz, patrząc na dzieje Izraela, wyjście i okres pustyni wiąże raczej z ludem zamieszkującym Królestwo Samarii. Brakuje jednoznacznej wzmianki mówiącej o włączeniu Judy w tę tradycję. ${ }^{41}$

Z historią wyjścia z Egiptu i pobytu na pustyni jest związane ogłoszenie Dekalogu. Dla proroka z pewnością wiele z czynów wymienionych w ramach przykazań było częścią składową zobowiązań wynikających z zawartego przymierza. ${ }^{42} \mathrm{~W} \mathrm{Oz} 4,2$, we fragmencie, który uprzedza obietnicę odnowienia przymierza, wymieniona jest lista przewinień, której słownictwo zdradza wspólne korzenie z dziesięcioma przykazaniami. ${ }^{43}$ Kolejność wymienionych przez proroka czynów różni się od tej, którą znajdujemy w przykazaniach Dekalogu. Ozeasz wymienia kolejno: ,zabójstwo” (רצח), ,kradzież” (גנב) i ,ccudzołóstwo" (נאף), używając tych samych słów, które znajdują się na tablicach przekazanych Mojżeszowi, aczkolwiek w innym porządku. Kolejność pojawiania się poszczególnych czynów jest różna od tej, którą znamy z tekstu masoreckiego, gdzie po kolei wymienione są: zabójstwo, cudzołóstwo i kradzież. Warto jednak zauważyć, że ta triada poważnych grzechów nie musiała zawsze funkcjonować w tej właśnie kolejności zaproponowanej przez tekst masorecki (Wj 20,13-15 i Pwt 5,17-19). Tekst grecki Dekalogu z LXX prezentuje inną kolejność: cudzołóstwo, kradzież, morderstwo. Kolejny układ tych

in Honor of John. H. Hayes, Sheffield 1993, s. 128; J. B l e n k i n s o p p, The Baal Peor Episode Revisited, Biblica 93/2012, s. 86-97.

40 Różne teorie odnośnie do identyfikacji tego proroka podaje m.in. W. P i k o r, Prorocka interpretacja exodusu, s. 48.

${ }^{41}$ Por. J. v a n S e te r s, Dating the Jahwist's History: Principles and Perspectives, Biblica 96/2015, s. 4.

42 Bo H. Li m, D. C a s te 11 o, Hosea, s. 117-118; por. E. B. Zv i, Hosea, FOTL 21A/1, Eerdmans, Grand Rapids 2005, s. 109; M. S z m a j d z i ń s k i, Ideat kapłana w Księdze Ozeasza, Verbum Vitae 17/2010, s. 102.

43 „Przeklinają, kłamią, mordują i kradną, cudzołożą, popełniają gwałty,

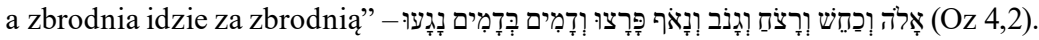


przykazań znajdziemy w Jr 7,9, gdzie pojawiają się w tej samej formie gramatycznej jak u Ozeasza (inf. abs.), ale w innej kolejności: kradzież, morderstwo i cudzołóstwo. ${ }^{44}$ Co to oznacza w odniesieniu do Oz 4,2? Można zauważyć istnienie bardzo starej tradycji zawierającej przekaz o zobowiązaniach wynikających z zawartego przymierza. Widać zbieżność słownictwa w Księgach: Wyjścia, Powtórzonego Prawa i Ozeasza, która wskazuje albo na wspólną tradycję, która była przekazywana w formie ustnej, albo też na fakt, że redaktorzy Księgi Wyjścia i Księgi Powtórzonego Prawa bazowali na treściach z Ozeasza. ${ }^{45}$ Tak twierdzą m.in. B. Lang H. D. Neef. Zdaniem tego ostatniego, w czasach Ozeasza istniała skrócona wersja Dekalogu obejmująca najbardziej istotne z punktu widzenia społeczności zakazy. Zwraca uwage przy tym, na u Ozeasza brak regulacji dotyczących szabatu czy też relacji wobec rodziców. ${ }^{46}$

$\mathrm{Z}$ tematem Dekalogu ściśle łączy się problematyka wędrówki po pustyni i temat przymierza. Wydaje się, że formuła z Oz 1,9 (,nie jestem waszym Bogiem"), wyraża zaprzeczenie deklaracji z Wj 6,7:

44 Zmianę kolejności przykazań znajdujemy również w relacjach ewangelistów, gdzie Mk 10,19 i Mt 19,18-19 idą za kolejnością zaproponowaną w TM i w Kpł 19,18, ale już Łk 18,20 prezentuje inną kolejność: cudzołóstwo, morderstwo, kradzież, podobnie jak w Rz 13,9.

45 Zdaniem Macintosha i wielu innych, pierwsza część rozdziału 4, mówiąca o odejściu od wierności i znajomości Boga, jest konstatacją złamanie pierwszego przykazania; A. M a c in to s h, A Critical and Exegetical Commentary on Hosea, s. 130-131.

46 B. L a ng, Monotheism and the Prophetic Minority: An Essay in Biblical History and Sociology, Almond Press, Sheffield 1983, s. 31; H. D. N e e f, Die Heilstraditionen Israels in der Verkündigung des Propheten Hosea, BZAW 169, Berlin 1987, s. 175-200; por. J. A. D e a r m a n, The Book of Hosea, s. 150-152. Można również doszukiwać się w kolejnych wymienionych przez proroka czynach: krzywoprzysięstwo i kłamstwo, powiązań z kolejnymi przykazaniami dekalogu. W pierwszym przypadku chodziłoby o łączenie krzywoprzysięstwa z brakiem uszanowania dla imienia Boga, natomiast kłamstwo łączyłoby się z zakazem dawania fałszywego świadectwa. 
„Ja jestem dla nich Bogiem”. ${ }^{47}$ Ta deklaracja ukazuje główną motywację działania Boga w stosunku do swego narodu. Ozeasz ją parafrazuje, pozwalając sobie na grę słów. ${ }^{48}$ które mają swoje zakorzenienie w tradycji formuły przymierza, zaczynającej się od słowa

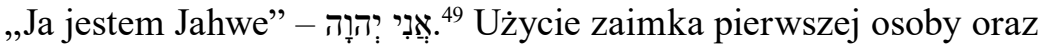
czasownik ,być”, który w Oz pojawia się kilkakrotnie w odniesieniu

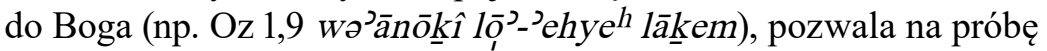
powiązania tego tekstu z Wj 3,14. ${ }^{50}$ Sam tekst z Wj 3,14 przedstawia imię Boga jako niejasną do końca grę słów opartą na rdzeniu „być” היה, z której można wyprowadzić imię Jahwe. Zdaniem A. Dearmana, słuchacze Ozeasza wydają się zaznajomieni z tą tradycją. Co więcej, Ozeasz rozwija i przepracowuje tę tradycję związaną z imieniem Boga i ją odwraca. Przesłanie pozytywne charakteryzujące Wj 3,14 zostaje odwrócone w ujęciu Ozeasza. ${ }^{51}$

47 W. P i k o r, Prorocka interpretacja exodusu, s. 49-50: „Sposób użycia tej formuły przez Ozeasza dowodzi, że funkcjonowała ona w połowie VIII w. jako niezależna wypowiedź w ramach liturgii (najprawdopodobniej w Betel). Zauważa się, że formuła zastosowana przez Ozeasza przypomina prolog historyczny do Deka$\operatorname{logu}(\mathrm{Wj} 20,2$; Pwt 5,6). Nie wydaje się jednak, że ten tekst jest źródłem, z którego korzysta prorok (kopiując lub czyniąc interpolację). Po pierwsze, w prologu do Dekalogu wyprowadzenie Izraela z Egiptu przez Jahwe oddane jest czasownikiem yāṣā’ w Hifil, podczas gdy Ozeasz używa w tym kontekście czasownika ‘ālā $h$ w Hi. Po drugie, dyskutowana formuła pojawia się w proroctwie Ozeasza poza „dekalogowym” kontekstem, łącząc się z ideą wędrówki przez pustynię".

48 Por. E. I. A nd er se n, D. N. Freed m a n, Hosea, s. 197-199. F. C. Fe n s h a m, The Marriage Metaphor in Hosea, JNSL 12/1984, s. 76; M. F. R o o k e r, The Use of the Old Testament in the Book of Hosea, Criswell Theological Review 7/1993, s. 56.

49 Por. C. S. E h rl i c h, The Text of Hosea 1:9, JBL 104/1985, s. 13-19.

50 D. S t u a r t, Hosea - Jonah, Word, Waco 1987, s. 33.

${ }^{51}$ Por. J. A. D e a r m a n, The Book of Hosea, s. 101. U proroka brakuje jasno sformułowanych motywów wyjścia z Egiptu. W opowiadaniach Wj 12 i 14 wyjście odbywa się na skutek nacisków ze strony faraona i jego dworu, którzy przymuszeni różnego rodzaju plagami wręcz wypędzają Izraelitów. Prorok wydaje się nie znać historii plag, które według Wj 12 są głównym powodem wypędzenia Hebrajczyków. Również samo zdarzenie niewoli egipskiej jest nieobecne w relacjach Ozeasza. Zdaniem Ska, opowiadanie o wyjściu zawarte w Wj 14 jest oparte na tradycji żywej 


\section{Wspólne motywy Księgi Powtórzonego Prawa i Ozeasza}

Oba dzieła zdradzają wielką liczbę wspólnych idei teologicznych i wzajemną zależność. Na szczególną uwagę zasługuje bliższe przyjrzenie się wzajemnym relacjom między Pieśnią Mojżesza z Pwt 32, 1-43 ${ }^{52}$ a tradycją zawartą u Ozeasza. Wielu egzegetów zauważa przedwygnaniowy charakter tego tekstu, który zdradza bardzo wiele wspólnych motywów z Księgą Ozeasza. ${ }^{53}$ Zdaniem U. Cassutto, utwór obecny w Pwt 32 został spisany jeszcze przed epoką Jeroboama II i miał bazować na tekście już spisanym. Prorok

w Królestwie Północnym, a obecnej w Oz 2,17; 11,1; 12,10.14. Tradycja znana Ozeaszowi została w Królestwie Południowym przepracowana i połączona z opisem plag, tworząc z czasem znany dzisiaj tekst masorecki Księgi Wyjścia; J. L. S k a, Introduzione alla lettura del Pentateuco, s. 279-280. „Jam jest Pan, Bóg twój, od ziemi egipskiej, dozwolę ci jeszcze zamieszkać w namiotach, jak było za dni Spotkania” (Oz 12,10) -, ,Lecz Pan wyprowadził Izraela z Egiptu przez proroka, i również przez proroka otoczył go opieką" $(\mathrm{Oz} 12,14)$.

52 „Uważajcie, niebiosa, na to, co powiem, słów moich ust słuchaj, ziemio. Nauka moja niech spływa jak deszcz, niech słowo me pada jak rosa, jak deszcz rzęsisty na zieleń, jak deszcz dobroczynny na trawę. Gdyż głosić chcę imię Pana: uznajcie wielkość Boga naszego; On Skała, dzieło Jego doskonałe, bo wszystkie drogi Jego są słuszne; On Bogiem wiernym, a nie zwodniczym, On sprawiedliwy i prawy. Zgrzeszyły przeciw $\mathrm{Ni}$ e m u «Ni e-J e g o-D z i e c i», lecz ich zwyrodnienie, pokolenie zwichnięte, nieprawe. Więc tak odpłacać chcesz Panu, ludu głupi, niemądry? Czy nie On twym oj c e m, twym s t w ó r cą? Wszak On cię uczynił, umocnił. Na dawne dni sobie wspomnij. Rozważajcie lata poprzednich pokoleń. Zapytaj ojca, by ci oznajmił, i twoich starców, niech ci powiedzą. Kiedy Najwyższy rozgraniczał narody, rozdzielał synów człowieczych, wtedy ludom granice wytyczał według liczby synów Izraela; bo Jego lud jest własnością Pana, dziedzictwem Jego wydzielonym jest Jakub. Na pustej zie mi go znalazł, n a pu st k ow i u, wśród dzikiego wycia, opiekował się nim i pouczał, strzegł jak źrenicy oka. Jak orzeł, co gniazdo swoje ożywia, nad pisklętami swoimi krąży, rozwija swe skrzydła i bierze je, na sobie samym je nosi - tak Pan sam go prowadził, nie było z nim boga obcego" (Pwt 32,1-12).

${ }_{53}$ J. A. D e a r m a n, The Book of Hosea, s. 353; por. P. S a n d e r s, The Provenance of Deuteronomy 32, Brill, Leiden 1996. 
mógłby posłużyć się gotowym tekstem i zreinterpretować go. ${ }^{54} \mathrm{Nie}$ musi to oczywiście oznaczać, że tekst dokładnie w tej formie pojawił się już przed upadkiem Samarii. Z kolei Dearman uważa, że z uwagi na jego poetycki charakter można stwierdzić, że zanim został on spisany, przeszedł dosyć długą drogę w formie ustnej. Wydaje się, że zarówno Ozeasz, jak i autor Pwt 32 korzystali z wspólnej tradycji ustnej. Bardzo rzuca się w oczy zbieżność tematyczna i leksykalna obu utworów. Najważniejszą analogią jest sposób opisywania relacji Boga z ludźmi za pomocą relacji ojciec - syn (Pwt 32,5. 18-20; Oz 1-3; $11,1 ; 13,13)$. Drugi podstawowy temat, to fakt znalezienie Izraela na pustyni (Pwt 32,10. Oz 9,10; 2, 16-17). Dodatkowo znajdujemy w obu utworach te same określenia: „syn niemądry” (Pwt 32,6; Oz 13,13), Bóg przedstawiony jest jako „twórca Izraela” (Pwt 36,5.15; Oz 8,14), Izrael prowokował Boży gniew przez relację z obcymi (Pwt 32,16; Oz 7,9; 8,7), pobudza Boga do gniewu (Pwt 32,16.21; Oz 12,15). Bożkowie w obu tekstach są określani za pomocą stwierdzenia „nie bogowie”, „nie bóg” (Pwt 32,17.21; Oz 8,6). Pojawia się wspólny motyw znania i nieznania Boga. Relacja z obcymi bogami jest określona jako cześć oddawana bożkom, których Izrael nie zna (Pwt 32,17; Oz 5,4; 13,16). W obu tekstach pojawiaj się motyw szkodliwych winogron, które symbolizują nieprzyjaciela lub sam Izrael (Pwt 32,32; Oz 10,1).

Na pogłębione studium zasługuje zbadanie wspólnych motywów między całością Księgi Powtórzonego Prawa i Księgi Ozeasza. Oprócz dużego podobieństwa pewnych sformułowań między Pwt 32 i Ozeaszem, uderzająca jest wspólna wizja Boga przedstawianego jako osoba - Ojciec, który kocha. Hebrajski rdzeń אהב, oznaczający „kochać” w odniesieniu do Boga lub do człowieka, występuje bardzo często w obu tych księgach - przypada na nie dwie trzecie występowania tego słowa w całej Biblii Hebrajskiej. Za pomocą tego terminu obie księgi opisują miłość Boga do swojego narodu (Oz 3,1b; 9,15; 11,1;

54 U. C a s s u t t o, The Prophet Hosea and the Books of Pentateuch, Biblical and Oriental Studies, t. I, Magness, Jerusalem 1973, s. 41-46; C. V a n g, God's Love according to Hosea and Deuteronomy. A Prophetic Reworking of the Deuteronomic Concept? Tyndalle Bulletin 62/2011, s. 173-194. 
14,5; Pwt 4,37; 7,8.13; 10,15; 23,6). ${ }^{55}$ Ozeasz używa tego wyrażenia również do określenia miłości między ludźmi, opisania relacji Izraela do obcych bogów lub upodobania w nich. ${ }^{56}$ Natomiast nigdzie nie używa słowa „,kochać” w celu opisania stosunku Izraela do Boga Jahwe w kontekście przymierza. U niego, jak się wydaje, miłość jest bardziej atrybutem Boga niż narodu. Ów termin służy u proroka nade wszystko do opisu nastawienia Jahwe. Kryje się w tym idea nowego przymierza, którego zasadniczą nowością jest to, że Bóg bierze zobowiązania na siebie, nie uważając za możliwe traktowanie narodu jako równoprawnego partnera przymierza, gotowego wypełnić wszystkie zobowiązania. ${ }^{57}$

Zdaniem wielu egzegetów, temat miłości jest najmocniejszym punktem stycznym między obiema księgami. ${ }^{58}$ Kwestią do rozstrzygnięcia pozostaje to, jaki jest rodzaj tej wzajemnej zależności? Co było najpierw? Niemiecki egzegeta Wolff w swoim komentarzu stwierdza, że Ozeasz jest swego rodzaju ,ojcem chrzestnym” dla Księgi Powtórzonego Prawa. Jego zdaniem, temat Bożej miłości został odkryty przez tego proroka. ${ }^{59}$ Miłość Boga wydaje się głównym motywem

55 „Pan rzekł do mnie: «Pokochaj jeszcze raz kobietę, która innego kocha, łamiąc wiarę małżeńską». Tak miłuje Pan synów Izraela, choć się do bogów obcych zwracają i lubią placki z rodzynkami” (Oz 3,1). „Uleczę ich niewierność i umiłuję ich z serca, bo gniew mój odwrócił się od nich” (Oz 14,5). „Miłujcie przeto Pana, Boga swojego, i wiernie przestrzegajcie Jego praw, poleceń i nakazów po wszystkie dni” (Pwt 11,1). „Lecz Pan, Bóg twój, nie chciał słuchać Balaama, i Pan, Bóg twój, zamienił przekleństwo względem ciebie na błogosławieństwo, bo Pan, Bóg twój, umiłował ciebie" (Pwt 23,6).

56 Por. K. Z o b e 1, Prophetie und Deuteronomium: die Rezeption prophetischer Theologie durch das Deuteronomium, de Gruyter, Berlin-New York 1992, s. 17-21.

57 Por. D. R. D a n i e l s, Hosea and Salvation History. The Early Traditions of Israel in the Prophecy of Hosea, de Gruyter, Berlin-New York 1990, s. 92-110; P. B ov a t i, La nuova alleanza: Dio cambia il cuore umano, w: G. R a v a s i (red.), La Bibbia per la famiglia, VII, Milano 1997, s. 268-272.

58 Por. M. W i e $\mathrm{n}$ f e $1 \mathrm{~d}$, Deuteronomy and the Deuteronomic School, Clarendon, Oxford 1972, s. 368; C. V a n g, God's Love, s. 173-174.

59 H. W. W o $1 \mathrm{ff}$, Dodekapropheton 1. Hosea, Neukirchenerverlag, Neukirchen-Vluyn, 1990, s. 26. 
wybrania narodu, który się przewija przez całą Księgę Ozeasza, natomiast redaktorzy Księgi Powtórzonego Prawa wydają się tymi, którzy przejęli i zreinterpretowali nauczanie tego proroka. ${ }^{60} \mathrm{~W}$ swojej epoce jedynie on rozwija ten temat. W Księdze Amosa co prawda dwukrotnie jest użyty ten rdzeń (Am 4,5 i 5,15), ale służy on do wyrażenia upodobania do czegoś, a nie do ukazania relacji międzyosobowej. Kolejni autorzy rozwijają tą kwestię pod kątem dawania pierwszeństwa Ozeaszowi w budowaniu teologicznego obrazu Bożej miłości. Zauważa się jednak inne rozłożenie akcentów w obu tekstach. Zobel stwierdza, że redaktorzy Księgi Powtórzonego Prawa, dokonując adaptacji Ozeaszowego obrazu, dokonali jego zubożenia przez eliminację bogactwa porównań i analogii, szczególnie tych związanych z małżeństwem. Widać wyraźnie obniżenie temperatury oraz uciekanie od emocjonalności, co można przypisać tendencji redaktorów tej księgi do unikania antropopatyzmów. ${ }^{61}$

Zdarzają się również opinie całkowicie odmienne. Zdaniem np. Rookera, Vanga i Bosa, to Ozeasz czerpie z tekstu Księgi Powtórzonego Prawa, który w jakimś stopniu miał już być gotowy w VIII w. przed Chr. ${ }^{62}$ Wydaje się jednak, że są to sugestie zbyt daleko idące. Jest pewien konsensus, który pozwala stwierdzić, że istnieje mnóstwo leksykalnych i tematycznych podobieństw w obu księgach. Temat miłości Boga pojawia się w kontekście wspólnym dla obu utworów, czyli: wyjście z Egiptu oraz wędrówki przez pustynię.

Ozeasz cztery razy notuje, że Bóg kocha Izraela (3,1; 9,15; 11,1-4

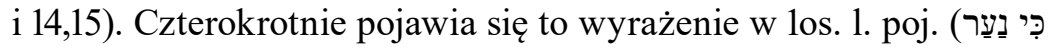

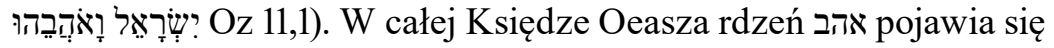
ok. 20 razy. Obiektem miłości Boga jest Izrael, Efraim lub dzieci Izraela. Warto zauważyć, że w cały ten kontekst miłości wpisuje się

${ }^{60}$ Odmienną opinię wyraża m.in. Vang, którego zdaniem, to Ozeasz czerpie motywy teologiczne z spisanego dzieła, które określa jako Ur-Deuteronomium; C. V a n g, The So-called „Ur-Deuteronomium“-Some Relections on Its Content, Size and Age, Hiphil 6 (2009)1, s. 1-18.

${ }_{61}$ Por. K. Z o b e 1, Prophetie und Deuteronomium, s. 86.

${ }^{62}$ Por. M. F. R o o ke r, The Use of the Old Testament in the Book of Hosea, s. 62 . 
także wyrażenie „być miłosiernym” (רחם), które także bardzo często pojawia się u Ozeasza ( 8 razy) i wydaje się być stosowane przez proroka synonimicznie do ,kochać” (אהב). Terminu אהב prorok nie używa w odniesieniu do relacji Izraela $\mathrm{z}$ innymi bogami w formie czasownikowej, natomiast bożkowie są określani dosyć często jako

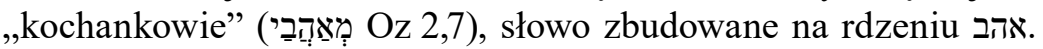
Natomiast warto zauważyć, że według narracji Księgi Powtórzonego Prawa to naród, bardziej niż Bóg, jest wezwany do kochania Boga (,Będziesz miłował [ וֹאָהִבְת ] Pana, Boga twojego, z całego swego serca, z całej duszy swojej, ze wszystkich swych sił" (Pwt 6,5; por. Pwt 5,10; 7,9; 10,12), oraz do kochania cudzoziemców (Pwt 10,19). ${ }^{63}$

Obrazy znane z Księgi Powtórzonego Prawa kontynuują pewne motywy z Księgi Ozeasza, ale dokonują również swoistej korekty. Oprócz wspólnego dla obu ksiąg rdzenia אהב, w Księdze Powtórzonego Prawa powtarza się חשק (Pwt 7,7; 10,15; 21,11) - ,kochać”, „przylgnąć”, który pojawia się wspólnie z terminem בחר -,wybrać”. Oba te czasowniki nie pojawiają się ani razu w Księdze Ozeasza.

${ }^{63}$ Według Ozeasza, miłość Boga przybrała konkretny wymiar w historii: Izrael został ukochany od początku istnienia jako naród, w Egipcie (11,1), a miłość przybrała swój konkretny wymiar w uwolnieniu od nieprzyjaciół $(13,4$ : „A to Ja jestem Pan, Bóg twój od ziemi egipskiej, innego Boga poza Mną ty nie znasz, nie ma prócz Mnie wybawcy"). Został wybrany na pustyni i na tej pustyni był otoczony opieką. Exodus jest motywowany miłością. Prorok ten obraz pogłębia poprzez ukazanie relacji: ojciec - syn, co pozwala jeszcze bardziej ukazać nowy wymiar przymierza, które akcentuje jego jednostronność, oraz brak warunków stawianych ludzkiemu partnerowi. Miłość ukazywana przez proroka jest bardzo emocjonalna (,A przecież Ja uczyłem chodzić Efraima, na swe ramiona ich brałem; oni zaś nie rozumieli, że troszczyłem się o nich. Pociągnąłem ich ludzkimi więzami, a były to więzy miłości. Byłem dla nich jak ten, co podnosi do swego policzka niemowlę - schyliłem się ku niemu i nakarmiłem go"; Oz 11,3-4). Uzupełnieniem tego obrazu jest idea gniewu, który jest poddany kontroli. Bóg nie ulega pokusie zniszczenia swego dzieła, ale dokonuje kolejnych prób aby przywrócić pierwotną harmonię. Uzupełnieniem obrazu ojca - syna, jest metafora małżeńska, która jest ukazana jako jeden z głównych motywów z Oz. Wymowa tego obrazu jest podobna jak w ikonie ojca-syna. Mimo niewierności i braku miłości jednej ze stron, Bóg pozostaje niezmienny w swoim wyborze; por. Y. H. K i m, Spiritual Restoration in the Prophecy of Hosea 2:16-25, Torch Trinity Journal 4/2001, s. 102-115. 
Warto zauważyć również tendencje zawarte w Księdze Powtórzonego Prawa do używania słowa עַ (,naród”), jako obiektu Bożej miłości. Ozeasz preferuje terminy „Izrael” lub „Efraim”. W Księdze Powtórzonego Prawa znajdziemy jeszcze jeden obiekt miłości, którym dla jej redaktorów jest ,obcy” - gēr (Pwt 10,18), kolejne słowo, którego Ozeasz nie używa w żądnym kontekście. Dla redaktorów Księgi Powtórzonego Prawa miłość wyraża się w pewnej formie ekskluzywizmu, który polega na wybraniu jednego narodu spośród wielu. Nie ma tutaj otwarcia na wymiar bardziej uniwersalny, który pojawia się u Ozeasza, chociażby w obrazie przymierza z wszystkimi istotami żywymi. Księga Powtórzonego Prawa akcentuje przymierze zawarte z „ojcami” i na wierności Boga, który kiedyś dał swoje słowo i w obecnej generacji je realizuje. Duchowy stan narodu w relacji księgi wygląda całkiem nieźle, natomiast według Ozeasza, naród pod względem duchowym jest w stanie katastrofy. ${ }^{64}$

Reasumując zależność między Księgą Ozeasza i Księgą Powtórzonego Prawa, możemy wymieć kilka podstawowych podobieństw oraz różnic. Najważniejsze punkty wspólne obu tekstów to: miłość Boga jest powodem wyprowadzenia z Egiptu i zawarcia przymierza na pustyni; zagrożeniem tej relacji jest nielojalność Izraela i nieposłuszeństwo przykazaniom. Oba teksty podkreślają brak zasług ze strony narodu, dzięki którymi mógłby on zasłużyć na akt Bożej miłości. Ozeasz podkreśla emocjonalność tej miłości. Księga Powtórzonego Prawa używa sporadycznie słowa ḥāšaq - „przylgnąć”, „kochać” - które może wyrażać relację intymną, pogłębia związek obu ksiąg wspólny motyw ojciec - syn. Tekst Księgi Powtórzonego Prawa akcentuje rolę przodków, jako pierwszego obiektu miłości. U Ozeasza odnosi się w praktyce jedynie do Jakuba. Prorok zauważa trwanie miłości mimo zdrady, natomiast Księga Powtórzonego Prawa akcentuje uwarunkowania tej relacji w odniesieniu do wierności przykazaniom. ${ }^{65}$

64 Por. C. V a n g, God's Love according to Hosea and Deuteronomy, s. 190.

65 Por. A. D e a r m a n, The Book of Hosea, s. 217-218. 
Podstawowe różnice, które można zaobserwować w obu dziełach: Ozeasz temat miłości odnosi do odległej przeszłości - gdy Izrael był „młody”. Stan rzeczy, który widzi on wśród sobie współczesnych, jest taki, że ta miłość zanikła, przynajmniej ze strony Izraela. Księga Powtórzonego Prawa ukazuje miłość jako coś aktualnego, część tej rzeczywistości, nie zaś tylko jako element historii. Ona zaczęła się w historii i trwa nadal. Izrael to rozeznaje i realizuje tu i teraz. U Ozeasza jednostronna miłość trwa, natomiast w świetle Księgi Powtórzonego Prawa jest uwarunkowana wiernością narodu. ${ }^{66}$ Największą różnicą między księgami jest brak w Księdze Powtórzonego Prawa metafory małżeńskiej oraz brak wzmianki o zdradzie małżeńskiej. Słowo נאף (,cudzołóstwo”) pojawi się tylko raz w Księdze Powtórzonego Prawa, w Dekalogu, natomiast Ozeasz użyje go pięciokrotnie. Słowo tak charakterystyczne dla Ozeasza, czylinנה (czynić nierząd”), pojawia się w Księdze Powtórzonego Prawa tylko trzy razy, w tym dwa razy odnośnie do prostytucji jako takiej i raz w Pwt 31,16 na określenie bałwochwalstwa (wydaje się, że jest to jeszcze późniejszy dodatek). Ozeasz zastosuje je 14 razy. Tym bardziej jest interesująca absencja tego obrazu w Księdze Powtórzonego Prawa, jeśli się zauważy, że mamy tam regulacje prawne odnośnie do nadużyć w małżeństwie (Pwt 22,13-29). Dla części egzegetów brak metafory małżeńskiej i cudzołóstwa, dowodzi tego, że Księga Powtórzonego Prawa lub pre-Księga jest tą tradycją, która była punktem wyjścia do refleksji zaprezentowanej w Księdze Ozeasza. Wydaje się, że ta metafora byłaby zbyt atrakcyjna, by jej nie zastosować. Dlatego sugeruje się, że to prorok zreinterpretował tradycję Bożej miłości z Księgi Powtórzonego Prawa. ${ }^{67}$ Również bezwarunkowe trwanie Bożej miłości, mimo zdrad, jest argumentem za tym, aby tekst księgi Ozeasza, a przynajmniej jego kolejną poważną redakcję, umieszczać

66 Por. K. Z o b e 1, Prophetie und Deuteronomium, s. 35-49.

67 Por. C. V a n g, God's Love according to Hosea and Deuteronomy, s. 193. 
w kontekście powygnaniowym i w kontekście powrotu z wygnania, które jest ukazane jaki triumf miłości nad karą i sądem. ${ }^{68}$

W badaniach nad złożonością redakcji Pięcioksięgu ważną rolę odgrywa Księga Ozeasza. To dzieło zawiera wiele motywów teologicznych, które znajdujemy również w Torze. Współcześnie zaczyna dominować opinia, że Pięcioksiąg jest dziełem w dużej mierze powygnaniowym, szczególnie w odniesieniu do patriarchów. Jednak jeśli przyjmiemy, że faktycznie większa część tekstu Księgi Ozeasz powstała w VIII w. przed Chr., to widzimy, że wiele idei teologicznych obecnych w Pentateuchu było znanych już w czasach tego proroka. $\mathrm{Na}$ szczególną uwagę zasługuje motyw stworzenia, wybrania na pustyni i wyjścia z Egiptu oraz ukazanie przykazań Dekalogu, jako elementu składowego zawartego przymierza. Zwraca na siebie uwagę fakt, że istnieje zbieżność idei między Księgą Ozeasza a Księgą Powtórzonego Prawa, ujawniająca się szczególnie we wspólnym obrazie ojca i syna, oraz w idei miłości Boga do swojego narodu. Księga Ozeasza prezentuje także wiele informacji na temat patriarchy Jakuba, które wskazują na to, że ta postać ma swoją starożytną historię.

\section{ks. Marek BEDNARSKI}

Słowa kluczowe: prorok Ozeasz, Pięcioksiąg, patriarcha Jakub, dekalog, przymierze, Wyjście

Keywords: prophet Hosea, Pentateuch, patriarch Jacob, Ten Commandments, covenant, Exodus

68 Por. J. L. L e e, Dio sono io, non un uomo. Santità ed amore illogico di Dio per il popolo di Israele in Os 11, Pontificia Università Urbaniana, Roma 2015. 


\section{The Motifs of the Pentateuch in the Book of Hosea}

Summary

In a study of the complexity of the redaction of the Pentateuch, the Book of Hosea plays an important role. This Book is a witness to many theological motifs which are also found in the Torah. Nowadays, the opinion is generally held that the Pentateuch is a predominantly post-exilic work, particularly in relation to the patriarchs. However, if we assume that in fact the majority of the text of Hosea was written in the eighth century B.C., it becomes evident that many of the theological concepts were already known in the time of Hosea. Particularly noteworthy is the idea of the creation of the People, their election in the desert and their bringing out of Egypt. The prophet shows us that the commandments of the Decalogue are a component of the covenant. Noteworthy is the fact that there is a convergence of ideas between Hosea and Deuteronomy, which is particularly exhibited in the common image of father and son, and in the idea of God's enduring love for his people. Hosea also presents a lot of information about the patriarch Jacob, which indicates that this figure has its own ancient history. 